Hans Petter Graver. Habilitet og bruk av rådgivere i offentlige

anskaffelsesprosesser. I: Tidsskrift for forretningsjus, 2005, s. 461-76.

Artikkelen er utgitt på Gyldendal Akademisk

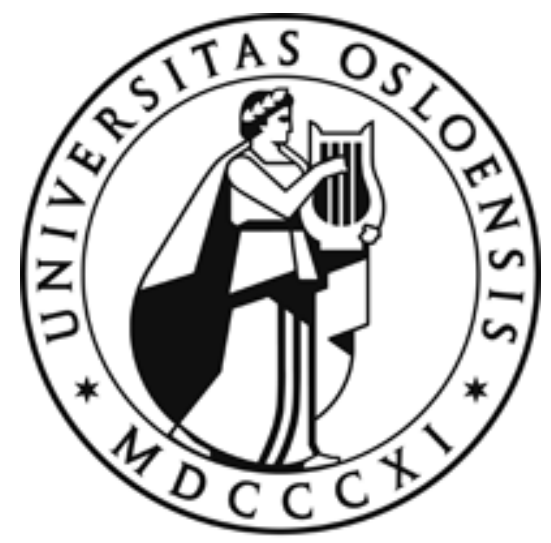




\title{
Habilitet og bruk av rådgivere $\mathrm{i}$ offentlige anskaffelsesprosesser ${ }^{1}$
}

\author{
Professor Hans Petter Graver
}

Hans Petter Graver

\section{Generelt om habilitet og offentlige anskaffelser}

Likebehandling og upartiskhet er bærende hensyn bak reglene om offentlige anskaffelser. Dette krever klare og objektive regler for behandling av potensielle leverandører av varer og tjenester til det offentlige. Like viktig er det at de som deltar i offentlige beslutninger om anskaffelser, ikke har personlige interesser på tvers av hensynet til nøytralitet og objektivitet i anskaffelsesprosessen. Hensynet til habilitet er kanskje særlig viktig i offentlige anskaffelser hvor det ofte er mange penger på spill, og mulighetene for korrupsjon, forskjellsbehandling og ufornuftig bruk av offentlige midler er store.

Kravene til habilitet reiser mange utfordringer. Familietilknytning mellom offentlige beslutningstakere og næringsdrivende som har virksomhet rettet inn mot det offentlige, reiser ofte problemer. Forbindelser av forretningsmessig karakter, enten de knytter seg til virksomhet som offentlig innkjøper eller til forretningsforbindelser som beslutningstakere har utenom sitt virke for det offentlige, reiser andre typer spørsmål. I grenselandet mellom offentlig og privat sektor oppstår ofte kompetanse- og vervkombinasjoner hos personer som både er beslutningstakere og styrerepresentanter i offentlig eide virksomheter eller offentlig-private samarbeidsprosjekter.

En egen type utfordring knytter seg til situasjoner der det offentlige knytter til seg rådgivere eller konsulenter for å bistå i anskaffelsesprosesser. Slike rådgivere har gjerne store deler av sin virksomhet rettet mot det private markedet, og de aktører som er aktuelle som tilbydere i forhold til en offentlig anskaffelse, utgjør ofte en viktig del av deres kundegrunnlag. Noen ganger er rådgiverne selv også produsenter eller leverandører av de aktuelle varer og tjenester. Innsikt i hvilke tekniske og kommersielle løsninger som finnes og hva markedet kan tilby, finnes først og fremst hos forhandlere og produsenter. Konsulenter selger ofte tjenester til de kommersielle aktørene i markedet. Dersom en konsulent har grunn til å tro at det kan styrke hans egen virksomhet for eksempel som produsent, leverandør eller rådgiver at en bestemt tilbyder vinner kontrakten, vil dette kunne påvirke hans vurderinger. Denne faren er enda sterkere om konsulenten selv er

1. Artikkelen bygger på en betenkning skrevet for Fagforbundet. 
potensiell leverandør eller står i et forretningsforhold til en eller flere av de potensielle tilbyderne.

Forvaltningsorganer vil ofte ha behov for å engasjere rådgivere til å bistå med hvordan de skal dekke sine behov for varer og tjenester. Spørsmålet kan være om det er best å dekke behovet gjennom egenproduksjon eller å gå ut i markedet. Dersom behovet skal dekkes i markedet, kan det være nødvendig med bistand både for å klarlegge hvilke tilbud som finnes, og hvordan det offentlige skal definere og presisere sine behov slik at det er mulig å gå til en kommersiell anskaffelse. Forvaltningen kan ha behov for bistand til å foreta forundersøkelser eller til å utarbeide de ofte meget detaljerte tekniske spesifikasjoner som trengs til å gjennomføre anskaffelsen. Regelverket om offentlige anskaffelser reiser kompliserte spørsmål av både kommersiell, teknisk og juridisk karakter. I denne forbindelse kan organet ha behov for bistand både til utforming av et tilbudsgrunnlag, gjennomføring av anskaffelsesprosessen og vurdering av de tilbud som er kommet inn i forhold til ??i forhold til hva??. Det forekommer også at en rådgiver gjennomfører anskaffelser på vegne av en offentlig myndighet.

Regler om rådgiveres habilitet blir derfor viktig for å sikre likebehandling av kommersielle aktører. Kravet til likebehandling finnes i den alminnelige forvaltningsrett, men har først og fremst betydning som et bærende prinsipp i anskaffelsesreglene. Habilitetsregler finnes både i forvaltningsloven og i reglene om offentlige anskaffelser. Forvaltningsloven $§ \$ 6-10$ inneholder de alminnelige forvaltningsrettslige habilitetsregler som gjelder all virksomhet til forvaltningsorganer. Disse gjelder generelt og er ikke spesielt tilpasset anskaffelsessituasjoner. I tillegg har vi habilitetsregler i anskaffelsesforskriften $§ \S 3-4$ og 3-6. Forskriften § 3-4 gir ingen egne habilitetsregler, men viser til forvaltningslovens alminnelige regler. Forskriften $§ 3-6$ innholder den særlige anskaffelsesrettslige habilitetsregel.

Mellom de forvaltningsrettslige regler og anskaffelsesreglene er det en forskjell i tilnærming. De forvaltningsrettslige reglene knytter seg til adgangen til å være med i behandlingen av en forvaltningssak. Anskaffelsesreglene knytter seg til likebehandling av markedsaktører og adgangen til å komme i betraktning som leverandør til det offentlige. Det særskilte anskaffelsesrettslige inhabilitetskravet knytter seg til det tilfellet hvor en rådgiver eller virksomhet etterfølgende deltar i den anskaffelse som han gjennom rådgivningsoppdraget har skaffet seg særlige kunnskaper $\mathrm{om} .^{2}$ Mens de forvaltningsrettslige habilitetsregler således regulerer hvem som kan være med i avgjørelsesprosessen, regulerer anskaffelsesreglene hvem som kan være med i konkurransen om offentlige oppdrag og hvordan de skal likebehandles.

2. Sml. Michael Steinicke, Tilbudsindhentning i bygge- og anlægssektoren, 2. utg., København 2003 s. 86. 
Anskaffelsesreglene har forankring i EØS-avtalen i tillegg til i den norske loven og forskriften om offentlige anskaffelser. EØSreglene inneholder ingen uttrykkelige generelle krav til habilitet hos oppdragsgiverens medarbeidere. At beslutningene skal være upartiske og at reglene dermed skal sikre dette, er likevel ikke tvilsomt. $^{3}$ Den særlige anskaffelsesrettslige rådgivningshabilitet er kommet til uttrykk i fortalen til direktivene, se senest pkt. 8 i direktiv 2004/18.

\section{De forvaltningsrettslige habilitetsregler}

Generelle hensyn i konkurranse- og anskaffelsessituasjoner

De forvaltningsrettslige habilitetsregler skal generelt sikre at forvaltningens avgjørelser blir forberedt og truffet av personer som står fritt og har en fri og ubundet innstilling til de saker som behandles. ${ }^{4}$ Ved regler om krav til å fratre ved saksbehandlingen i tilfeller av inhabilitet, reduserer forvaltningen risikoen for at det senere kan reises tvil om utenforliggende hensyn har vært trukket inn ved behandling av saken. Inhabilitetsreglene bidrar således til å sikre og styrke tilliten til forvaltningens avgjørelser. Dette er også en viktig del av deres formål.

I en konkurransesituasjon kommer særlige hensyn inn i bildet. Generelt kan det være grunn til en noe strengere praktisering av habilitetsreglene enn ellers, se Rt. 1998 s. 1398 Torghatten. En slik strengere praktisering understøttes også av anskaffelsesrettens likebehandlingskrav. På den annen side må ikke habilitetsreglene praktiseres slik at det offentlige i praksis blir avskåret fra å søke bistand fra markedsaktører til konkretiseringen og oppfyllelsen av sine behov i forhold til hva markedet kan tilby. Dette vil kunne hindre at det offentlige får kvalifisert bistand til å konkretisere sine behov og finne de beste løsninger i markedet. Reglene må heller ikke utelukke suksessiv utvikling av et prosjekt eller at en som tidligere har levert varer eller tjenester til det offentlige, er utelukket fra videre oppdrag. Hvis den som er engasjert til å bistå det offentlige og utvikle tjenestene i en tidlig fase uten videre er utelukket fra å levere i senere faser av prosjektene, vil det både kunne føre til at det blir vanskelig å få tilbydere til en tidlig fase i et prosjekt, og effektivitetstap ved skifte av leverandør uten at det er begrunnet i konkurransemessige hensyn.

En for streng praktisering av habilitetsreglene kan dessuten komme i konflikt med anskaffelsesreglenes krav til likebehandling. Dette er overtrådt dersom en markedsaktør automatisk er utelukket fra å få oppdrag i tilknytning til forberedelsen av en anskaffelse av den grunn at han også vil kunne være aktuell som

3. Se bl.a. EF-domstolens dom i sak C-458/03 Parking Brixen GmbH, ennå ikke i Saml. avsnitt 49.

4. Se Hans Petter Graver, Alminnelig forvaltningsrett, 2. utg. Oslo 2002 s. 317. 
tilbudsgiver ved den senere anbudskonkurransen, se EF-domstolens avgjørelse i Fabricom. ${ }^{5}$ Saken gjaldt hvorvidt en rådgiver kunne utelukkes fra å delta i konkurransen om oppdraget uten å få mulighet til å godtgjøre at han ikke hadde oppnådd noen konkurransefordel. Tilsvarende må imidlertid gjelde dersom habilitetsreglene praktiseres slik at en aktør utelukkes fra rådgivningsoppdrag uten at dette kan ses som nødvendig og forholdsmessig i forhold til likebehandlingskravet.

Siden konkurransen på denne måten kommer inn både som et moment som tilsier ekstra varsomhet, men også som et moment som tilsier fleksibilitet i forhold til de særlige kommersielle hensyn som gjør seg gjeldende, kan det argumenteres for at anskaffelsesreglene burde inneholdt habilitetsregler spesielt tilpasset denne situasjonen. Til en illustrasjon av hvordan de kunne vært utformet, kan en se på modeller fra andre land. Et eksempel er den tyske anskaffelsesforordningen $§ 16$. I tysk rett kommer de alminnelige forvaltningsrettslige habilitetsregler ikke til anvendelse på det offentliges forretningsvirksomhet. Etter at en domstol likevel hadde gitt habilitetsreglene anvendelse på en offentlig anskaffelse ut fra analogibetraktninger, ble det gitt egne bestemmelser i 2001. ${ }^{6}$ Habiliteten til konsulenter og rådgivere er her regulert

5. Forente saker C-21/03 og C-34/03 Fabricom SA mot Belgia, ennå ikke i Saml.

6. Se Hans-Joachim Priess, Distortions of Competition in Tender Proceedings: How to Deal with Conflicts of Interest (Family Ties, Business Links and CrossRepresentation of Contracting Authority Officials and Bidders) and the Involvement of Project Consultants, (2002) 11 P.P.L.R. s. 153-171. Bestemmelsen lyder:

Verordnung über die Vergabe öffentlicher Aufträge § 16 Ausgeschlossene Personen:

(1) Als Organmitglied oder Mitarbeiter eines Auftraggebers oder als Beauftragter oder als Mitarbeiter eines Beauftragen eines Auftraggebers dürfen bei Entscheidungen in einem Vergabeverfahren für einen Auftraggeber als voreingenommen geltende natürliche Personen nicht mitwirken, soweit sie in diesem Verfahren

1. Bieter oder Bewerber sind,

2. einen Bieter oder Bewerber beraten oder sonst unterstützen oder als gesetzliche Vertreter oder nur in dem Vergabeverfahren vertreten,

3. a) bei einem Bieter oder Bewerber gegen Entgelt beschäftigt oder bei ihm als Mitglied des Vorstandes, Aufsichtsrates oder gleichartigen Organs tätig sind oder

b) für ein in das Vergabeverfahren eingeschaltetes Unternehmen tätig sind, wenn dieses Unternehmen zugleich geschäftliche Beziehungen zum Auftraggeber und zum Bieter oder Bewerber hat, es sei denn, dass dadurch für die Personen kein Interessenkonflikt besteht oder sich die Tätigkeiten nicht auf die Entscheidungen in dem Vergabeverfahren auswirken.

(2) Als voreingenommen gelten auch die Personen, deren Angehörige die Voraussetzungen nach Absatz 1 Nr. 1 bis 3 erfüllen. Angehörige sind der Verlobte, der Ehegatte, Lebenspartner, Verwandte und Verschwägerte gerader Linie, Geschwister, Kinder der Geschwister, Ehegatten und Lebenspartner der Geschwister und Geschwister der Ehegatten und Lebenspartner, Geschwister der Eltern sowie Pflegeeltern und Pflegekinder. 
særskilt. En som har oppdrag i tilknytning til anskaffelsesprosessen, er inhabil om han på samme tid har forretningsmessige forbindelser både til oppdragsgiver og en tilbyder eller en som deltar i konkurransen. Inhabiliteten gjelder likevel ikke dersom det ikke foreligger noen interessekonflikt eller dersom forbindelsen ikke har virket inn på vurderingen. Dersom det foreligger rom for skjønn i anskaffelsesprosessen, må inhabilitet være hovedregelen dersom de objektive krav er oppfylt. ${ }^{7}$

\section{De forskjellige faser i anskaffelsesprosessen}

Siden det ikke gjelder egne habilitetsregler i norsk rett for anskaffelsessituasjoner, må vi ta utgangpunkt i forvaltningslovens generelle bestemmelser. Ved vurderingen av hvordan disse slår inn, er det hensiktsmessig å skille mellom forskjellige faser i en offentlig beslutning om å dekke sine behov i markedet. For det første har vi den fasen hvor det offentlige vurderer innkjøp i markedet som alternativ til å dekke behovet ved egne enheter eller ved å holde fast ved en etablert løsning. Ved denne fasen gjelder ikke anskaffelsesreglene. Verken disse eller EØS-reglene generelt etablerer noen plikt for det offentlige til å gå ut i markedet for å dekke sine behov. ${ }^{8}$ Denne beslutningen reguleres derfor utelukkende av de forvaltningsrettslige regler.

Et særtrekk ved denne fasen er at de beslutninger som treffes bare indirekte berører aktører i markedet. Det er i liten grad mulig å identifisere aktører som har forvaltningsrettslig partsstatus. Hvor det er snakk om å vurdere konkurranseutsetting, vil saken berøre enheter innad i forvaltningsorganet selv. Disse har verken partsstatus eller klagerett. I tillegg vil interessene til de ansatte i de aktuelle enheter være berørt. Disse har imidlertid heller ikke status som parter i saken, selv om de muligens i enkelte situasjoner vil kunne ha rettslig klageinteresse og søksmålsadgang. ${ }^{9}$ Hvor det er tale om å vurdere skifte av leverandør, vil den eksisterende leverandøren ha status som part i forvalt-

7. Se Hans-Joachim Priess, Distortions of Competition in Tender Proceedings S. 164.

8. Se nærmere Hans Petter Graver, Offentlige anskaffelser og interkommunalt samarbeid, TfR 2005 s. 153-187 særlig s. 157.

9. Se avgjørelsen i Rt. 2001 s. 1505 hvor førstvoterende uttalte at arbeidstakerne som utgangspunkt ikke kan gå til søksmål fordi den bedrift eller enhet de arbeider i, er forbigått i en anbudskonkurranse, men likevel ikke utelukket «at det kan oppstå tvilssituasjoner der avgjørelsen av anbudskonkurransen har stor betydning for arbeidstakerne, og der det etter en helhetsvurdering kan fremstå som rimelig å gi en fagforening søksmålskompetanse, slik at tvisten kan bedømmes av et organ utenfor kommunen.» I dansk rett er en rekke organisasjoner, herunder arbeidstakerorganisasjoner, gitt klagerett for Klagenævnet for udbud, se Ruth Nielsen, Udbud af offentlige kontrakter, 3. utg., København 2005 s. 324. 
ningsrettslig forstand. Potensielle deltakere i konkurransen vil derimot ikke være parter før de har inngitt tilbud.

Neste fase i en beslutningsprosess inntrer der det er truffet avgjørelse om konkurranseutsetting og anbudskonkurransen forberedes. Her vil det være tale om arbeid knyttet til markedsundersøkelse og andre studier, forprosjektering og forsøk, analyser, beregninger etc., samt fastsetting og utforming av kontraktsbetingelser og tekniske spesifikasjoner. Anskaffelsesforskriften § 3-4 bestemmer at reglene om habilitet i forvaltningsloven $§ 6$ til $§ 10$ og kommuneloven $\S 40 \mathrm{nr}$. 3 gjelder ved behandling av saker om offentlige anskaffelser. Der forvaltningsloven ikke direkte kommer til anvendelse, gjelder reglene i forvaltningsloven $\S 6$ til $§ 10$ tilsvarende. Hvor oppdragsgiveren er et forvaltningsorgan i forvaltningslovens forstand, vil hensvisningen i anskaffelsesforskriften ikke ha selvstendig materiell betydning. Forskriften har bare materiell betydning overfor offentlige oppdragsgivere som faller utenfor definisjonen av forvaltningsorgan i forvaltningsloven $§ 1$. Prosessuelt innebærer den imidlertid at overtredelse av forvaltningslovens habilitetsregler kan behandles etter de særlige tvisteløsningsreglene i anskaffelsesloven, se $\S \S 7$ og 7a og forskriften $\S 6$, og at de forvaltningsrettslige habilitetsreglene kan håndheves av Kofa. ${ }^{10}$

Endelig har vi den fasen der tilbudene er kommet inn og vurderes mot konkurransegrunnlaget og hverandre. Også her vil forvaltningsloven og anskaffelsesreglene gjelde parallelt. I denne fasen vil saken ha definerte parter, nemlig de som har inngitt tilbud. Koblingen mellom de råd som gis og de konkrete virkninger dette får for bestemte foretak, vil derfor gjennomgående være mye mer direkte enn i fasene før tilbud innhentes. Dette betyr at det blir lettere å identifisere sammenhenger mellom de råd som gis og de konsekvenser dette har for interessene til rådgiveren eller andre som denne har et tilknytningsforhold til.

\section{Habilitetsreglenes anvendelse på private rådgivere og konsulenter}

De alminnelige forvaltningsrettslige habilitetsreglene knytter seg til det å «tilrettelegge grunnlaget for en avgjørelse eller treffe en avgjørelse i en forvaltningssak», jf. innledningsordene i forvaltningsloven (fvl.) $§ 6$ første ledd. Reglene kommer ikke bare til anvendelse på personer som er ansatt i forvaltningsorganet, men også på personer som utfører oppdrag for det offentlige, for eksempel som en rådgivnings- eller tilretteleggingstjeneste. ${ }^{11}$ Dette

10. Dette i motsetning til hva som gjelder f.eks. i Danmark, hvor Klagenævnet ikke har kompetanse til å håndheve forvaltningslovens regler om inhabilitet, se Michael Steinicke, Tilbudsindhentning i bygge- og anlægssektoren, 2. utg., København 2003 s. 22-23.

11. Se Hans Petter Graver, Alminnelig forvaltningsrett, 2. utg. Oslo 2002 s. 319. 
følger av forvaltningsloven $§ 10$ som sier at habilitetsbestemmelsene foruten for offentlige tjenestemenn gjelder «tilsvarende for enhver annen som utfører tjeneste eller arbeid for et forvaltningsorgan». Anvendelsen av reglene er således knyttet til personer når de utfører oppgaver for det offentlige, enten dette skjer i et formelt ansettelsesforhold eller gjennom annen tilknytning. Tilknytningen kan være et verv eller ombud, et oppdrag osv., for eksempel det at en arkitekt er engasjert i kommunens reguleringsarbeide, se Sivilombudsmannens årsmelding 1979 s. 95 eller der en privatpraktiserende advokat utfører et konkret oppdrag fra en kommune, se Sivilombudsmannens årsmelding 1979 s. 68. Habilitetsreglene gjelder således ikke bare virksomhet som drives i forvaltningsorganer, men også personer som ellers handler for det offentlige, selv om det skjer utenfor de regulære forvaltningsorganer. Det avgjørende for om reglene kommer til anvendelse på oppdragstakere og tjenesteytere er derfor om det konkrete oppdraget faller inn under det å tilrettelegge grunnlaget for eller treffe avgjørelse i en forvaltningssak.

Det er ikke tvilsomt at en offentlig anskaffelse er en forvaltningssak. Alt arbeid som gjøres i tilknytning til forberedelse og gjennomføring av en anskaffelse, er således omfattet av regelen. Også spørsmålet om å konkurranseutsette en virksomhet må anses som en «forvaltningssak». Habilitetsreglene gjelder derfor også rådgivere som benyttes for å vurdere dette spørsmålet. Vurderingen må skje med utgangspunkt i hvordan deres interesser vil kunne bli berørt av beslutninger som treffes i de ulike faser av en sak om konkurranseutsetting.

\section{Inhabilitet på grunn av partsinteresser}

Forvaltningsloven $§ 6$ første ledd inneholder de absolutte inhabilitetsgrunner. En sentral inhabilitetsgrunn i forhold til rådgivning i en anskaffelsesprosess er regelen i første ledd bokstav b om inhabilitet for en part i saken. Dette kan bety at et foretak som er part i saken ikke, kan bistå oppdragsgiveren i anskaffelsesprosessen. Forvaltningsloven gjelder direkte for fysiske personer og ikke for selskaper. Det er alminnelig antatt at upersonlige rettssubjekter ikke faller direkte inn under forvaltningsloven $§ 10$. Hvor et foretak har økonomisk interesse i utfallet av en offentlig beslutning, vil personer som er ansatt i selskapet lett være inhabile etter forvaltningsloven $§ 6$ annet ledd. Generelt må det derfor antas at personer som er ansatt hos en part i anskaffelsessaken, ikke kan opptre som rådgivere i oppdragsgiverens behandling av anskaffelsen.

Et springende punkt i forhold til bruk av rådgivere som selv er markedsaktører og potensielle tilbydere, blir derfor når partsstatus inntrer og hvem som er parter i en anskaffelsessak. Ser vi på de forskjellige stadier som er skissert ovenfor, må det være klart at når tilbudene er kommet inn, vil alle tilbyderne være part. Det

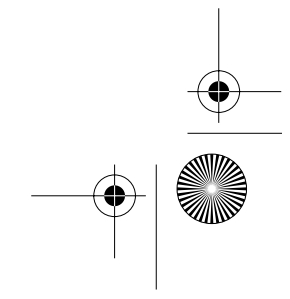


betyr at habilitetsreglene utelukker en tilbudsgiver fra å delta i prosessen med å vurdere tilbudene. Dette er også lagt til grunn av Kofa i Media Farm. ${ }^{12}$ Oppdragsgiver hadde benyttet seg av en person som var ansatt hos en av de aktuelle tilbudsgivere som konsulent. Konsulenten deltok i utformingen av konkurransegrunnlagets kravspesifikasjon og videre i evalueringen av de innkomne tilbudene. At konsulenten deltok i evalueringen etter at hennes arbeidsgiver hadde inngitt et tilbud, var brudd på forvaltningsloven $\S 6$ selv om ansvaret for evalueringen og administrasjonen av konkurransen lå hos en annen konsulent.

At tilbyderne og deres representanter er utelukket fra å delta i vurderingen og utvelgelsen av de innkomne budene, følger for øvrig også av det anskaffelsesrettslige forhandlingsforbudet. Dette forbudet innebærer at drøftelser med tilbyderne bare må skje med sikte på å supplere innholdet av deres bud eller myndighetenes krav, og på en måte som ikke fører til forskjellsbehandling av tilbyderne. ${ }^{13}$

I fasene av saken forut for utlysningen, er det ikke klart hvem som vil bli parter i saken. Den blotte mulighet for at en rådgiver kan komme til å inngi tilbud, er neppe nok til å bringe $§ 6$ første ledd $\mathrm{b}$ til anvendelse. Rådgiverens inhabilitet må i slike tilfelle vurderes ut fra den skjønnsmessige bestemmelsen i annet ledd.

Det finnes ingen praksis som direkte belyser dette spørsmålet i forhold til offentlige anskaffelser. Fra andre områder kan finnes eksempler som belyser hvordan mulige partsinteresser i en sak kan påvirke habilitetsvurderingen. I Sivilombudsmannens årsmelding 1979 s. 95 uttalte ombudsmannen at en arkitekt var inhabil til på oppdrag for kommunen å utarbeide en soneplan over et område hvor han selv og hans familie hadde eiendommer og industriinteresser. Det springende punkt i saken var om arkitekten eller hans familie kunne anses som part i plansaken. Den omstendighet at en person er grunneier innenfor et område, var i seg selv ikke nok til at vedkommende kunne regnes som part ved utarbeidelsen av soneplaner. Det måtte foretas en helhetsvurdering hvor et moment av betydning ville være hvorvidt arkitekten fikk spillerom for egne vurderinger i planleggingsarbeidet, eller om kommunen hadde gitt helt bestemte direktiver om hvordan man ønsker planene utarbeidet. Hvis arkitekten fikk valgmulighet m.h.t. arealdisponeringen innenfor planområdet, måtte det være av betydning hvorvidt valgmulighetene kunne få noen praktisk/ økonomisk betydning for arkitekten eller hans familie.

Også i forhold til rådgivere forut for en anskaffelsesprosess må det foretas en helhetsvurdering, der muligheten for at rådgiveren selv vil kunne komme til å konkurrere om leveransen må ha betydning. I tillegg må det legges vekt på i hvor stor grad opp-

12. KOFA-2003-86 Media Farm AS mot Jernbaneverket Norsk Jernbanemuseum.

13. Se Ruth Nielsen, Udbud af offentlige kontrakter, 3. utg., København 2005 s. 78.

\section{8}


dragsgiverens behov kan tilpasses nettopp denne leverandørens produkter eller tjenester, eller om tilbudene på markedet er nokså standardiserte. Betydningen av dette momentet øker selvsagt jo nærmere man kommer utarbeidelse av de tekniske krav som skal ligge til grunn for konkurransen om oppdraget.

\section{Inhabilitet som følge av tilknytning til en part}

Også representanter eller fullmektiger for parter er inhabile. Etter $\S 6$ første ledd bokstav d er en person inhabil «når han er verge eller fullmektig for en part i saken eller har vært verge eller fullmektig for en part etter at saken begynte». Forutsetningen for at dette alternativet skal komme til anvendelse, er at personer opptrer eller har opptrådt for parten i den angjeldende saken. Opptrer vedkommende eller har vedkommende opptrådt for parten i andre saker, faller tilfellet ikke inn under den absolutte inhabilitetsgrunnen i $\$ 6$ første ledd. Forholdet kan imidlertid falle inn under bestemmelsens annet ledd. Høyesteretts kjæremålsutvalg har behandlet den tilsvarende problemstilling i forhold til sakkyndiges habilitet etter domstollovens regler. I Rt. 1996 s. 1573 sa kjæremålsutvalget at «den som har bistått en part i en sivil sak som privatengasjert sakkyndig, står i et slikt forhold til parten at han som regel ikke bør oppnevnes mot den annen parts protest, når dette kan unngås, jf tvistemålsloven $§ 242$ annet ledd sammenholdt med domstolloven § 108». Det dreide seg her om en lege som hadde skrevet en privat sakkyndigerklæring for skadelidte i en forsikringssak i byretten, og som skadelidte ville ha oppnevnt som sakkyndig for lagmannsretten.

Nevnes kan også en sak i Sivilombudsmannens årsmelding 2002 s. 310 som gjaldt hvorvidt en arkitekt som hadde representert interessentene på en tomt i en forutgående byggesak, var inhabil til å delta i kommunens forberedelse av en reguleringsplan for tomten. Arkitekten representerte tomteeieren og arbeidet direkte for denne i den forutgående byggesaken. Byggesøknaden ble avslått av fylkesmannen etter klage bl.a. som følge av at den var i strid med gjeldende reguleringsplan. Den reguleringsplan som ble utarbeidet etterpå, var tilnærmet identisk med byggesøknaden som ble avslått. Ombudsmannen fant at arkitekten måtte være inhabil til å tilrettelegge grunnlaget for reguleringsvedtaket. Han fant at mye talte for à si at arkitekten hadde opptrådt som part eller som fullmektig for en part i saken tidligere, uten at han tok endelig stilling til dette. Uansett måtte inhabilitet foreligge etter $\S 6$ annet ledd. Den nære tilknytningen arkitekten hadde hatt både til eieren og kommunen, ville utad kunne oppfattes som en nær og uheldig tilknytning mellom den ene parten i saken og kommunen og måtte være å anse som «andre særegne forhold» som var egnet til å svekke tilliten til hans upartiskhet.

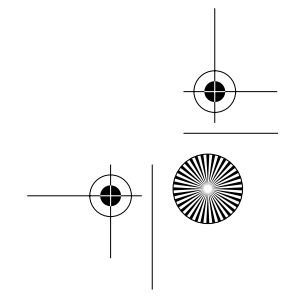


Når rådgiveren ikke er fullmektig i første ledds forstand, er det avgjørende om det foreligger «særegne forhold» i forhold til annet ledd. I konkurransesituasjoner er det videre slik at forholdet som må vurderes som regel er om avgjørelsen kan innebære en «særlig fordel, tap eller ulempe» for vedkommende selv eller noen han har en nær tilknytning til. De momenter som er trukket frem i de to sakene det er vist til ovenfor tilsier at den som har hatt fullmektig- eller representasjonsoppdrag for et eller flere av de selskaper som er part i en konkurranse om en offentlig kontrakt, ikke kan brukes som rådgiver i tilretteleggelse eller gjennomføring av den offentlige anskaffelsen etter at tilbud er kommet inn, dvs. den tredje fasen som er skissert.

Inhabilitet etter annet er ledd er ikke begrenset til fullmektiger og representanter. Også hvor det foreligger økonomiske forbindelser mellom rådgiveren og noen av tilbyderne, vil avgjørelse i saken kunne være til særlig fordel for en part som rådgiveren har særlig tilknytning til, se i forhold til vurderingen etter domstolloven $§ 208$ Rt. 1976 s. 168. Det firma den ene domsmann var eneinnehaver av, hadde i de senere år hatt flere betydelige arbeider for kommunen som hadde medført omfattende kontakt med de kommunale organer parten hadde beskyldt for klanderverdige handlinger. Sett på bakgrunn av den relativt omfattende kontakt og det samarbeid domsmannens firma hadde hatt, hadde og vel måtte forventes å ville ha fremover i tiden med nettopp disse kommunale organer, antok Høyesterett at innehaveren ikke skulle gjort tjeneste som domsmann i saken. Det hadde ingen betydning at domsmannen hadde fått oppdragene for kommunen gjennom anbud, dvs. på grunnlag av objektive kriterier.

Forretningsmessige forbindelser med en part behøver ikke ha noen innflytelse på de råd som gis til det offentlige. Avgjørende er om dette objektivt sett må sies å utgjøre særegne omstendigheter som er skikket til å svekke tilliten til en persons uhildethet. Slike forhold vil lett kunne påvirke allmenhetens tillit til om myndighetenes beslutning bygger på en upartisk og uavhengig vurdering. En rådgiver som allerede er forretningsmessig knyttet til en av de aktuelle tilbudsgivere vil lett komme i denne kategori. Som nevnt ovenfor har man bl.a. i tysk rett lagt inn en lovpresumsjon for inhabilitet i slike tilfeller. Omfanget av den økonomiske forbindelse må likevel være av betydning, se Rt. 1961 s. 1300 hvor honorarer fra kommunen som over en tiårsperiode utgjorde ca. 3 \% av firmaets bruttoinntekter ikke var nok til å gjøre innehaveren inhabil som domsmann.

På den annen side kan ikke uten videre den blotte utsikten til å få et slikt oppdrag for den som får kontrakten gjøre vedkommende inhabil som rådgiver. I den forbindelse kan det vises til uttalelsen fra Kofa i Lønnheim Entreprenør. ${ }^{14}$ En kommune hadde benyttet seg av et arkitektfirma til å utarbeide spesifikasjo-

14. KOFA-2003-272 Lønnheim Entreprenør AS mot Asker kommune. 
nene i konkurransegrunnlaget, samt til å bistå kommunen ved evalueringen av tilbudene. Det var anledning til å levere inn alternativt tilbud. Konkurransegrunnlaget bestemte at kommunens rådgivere kunne benyttes av totalentreprenøren til den videre prosjektering, hvis partene ble enige om dette.

Klageren hevdet at rådgiveren var inhabil til å evaluere tilbudene i en sak. Konkurransegrunnlaget åpnet adgang for rådgiveren til å bli engasjert av den som vant konkurransen, og dette etablerte et økonomisk motiv da rådgiveren ville ha større mulighet for ytterligere oppdrag ved å anbefale det alternativet de selv hadde utarbeidet. Kofa var i tvil med hensyn til om forvaltningslovens habilitetsregler kom til anvendelse. Etter Kofas oppfatning kunne det ikke utelukkes at en rådgiver som på en slik eksplisitt måte får varsel om muligheten for et videre engasjement også vil kunne trekke muligheten for å oppnå et slikt engasjement inn i evalueringen av tilbudene, bevisst eller ubevisst. Potensielt kan en rådgiver i en slik situasjon oppnå økonomisk vinning ved å velge den leverandøren som - erfaringsmessig eller på grunnlag av konkret kunnskap - mest sannsynlig vil gi dem kontrakt eller kontrakt på best vilkår. Kofa fant likevel under tvil at denne muligheten var så avledet og fjerntliggende i den konkrete saken at rådgiveren ikke var inhabil til å delta med sine råd under oppdragsgivers evaluering av tilbudene.

Det kan diskuteres i hvilken utstrekning reglene om inhabilitet for fullmektiger og representanter kan overføres til meglere for eksempel i forsikring. Forsikringsformidlingsloven skiller i § 1-2 mellom forsikringsmegling og forsikringsagentvirksomhet. Forsikringsmegling består i å gi kunden råd ut fra en analyse av et så stort antall av de på markedet disponible forsikringsløsninger som mulig, eller virksomhet som består i å presentere kunden for forsikringsløsninger fra et eller flere forsikringsselskaper, uten at det er inngått uttrykkelig avtale med forsikringsselskapene om dette. Forsikringsagentvirksomhet er forsikringsformidlingsvirksomhet som består i å tilby forsikringsprodukter for og på vegne av et eller flere forsikringsselskap. Ut fra disse definisjonene vil en forsikringsagent falle inn under alternativet i forvaltningsloven $\S 6$ første ledd bokstav d. Agenten tilbyr forsikringer på vegne av ett eller flere forsikringsselskap. Større tvil knytter seg til om forsikringsmeglere rammes av bestemmelsen.

Forsikringsmegling er pr. definisjon en virksomhet som drives uten uttrykkelig avtale med forsikringsselskapene. Megleren er engasjert av oppdragsgiver og skal ivareta oppdragsgiverens interesser uavhengig av hvilket forsikringsselskap som tilbyr forsikringen. Etter kravene til god meglerskikk i § 5-2 må forsikringsmeglingsforetaket ikke opptre på en måte som er egnet til å skape tvil om dets stilling som uavhengig mellomledd. En forsikringsmegler vil likevel kunne ha inngått en rammeavtale med en eller flere forsikringsleverandører og vil kunne ha store deler av sin virksomhet knyttet til en bestemt forsikringsleverandør. Slike

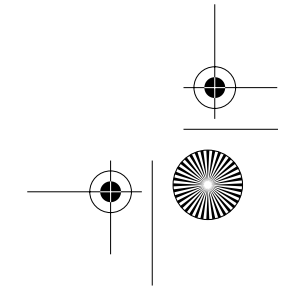


forhold kan trekke meglerens habilitet i tvil. Det er derfor viktig for kunden å få opplysninger om forholdet mellom meglerforetaket og forsikringsselskapet de megler forsikringer for. Dersom meglerforetaket mottar provisjon eller godtgjørelse i en eller annen form fra forsikringsselskapet, kan dette ha innvirkning på meglers uavhengighet, og slike opplysninger kan igjen ha innvirkning på kundens valg av megler. Loven pålegger på denne bakgrunn megleren opplysningsplikt om bl.a. størrelsen på provisjon/ godtgjørelse som meglerforetaket mottar fra forsikringsselskaper.

Siden megleren har en lovfestet plikt til å opptre uavhengig av forsikringsgivere, kan det forhold at han mottar provisjon fra en part neppe likestilles med å opptre som representant eller fullmektig i habilitetsreglenes forstand. Det kan også argumenteres for at forsikringsformidlingslovens pålegg til megleren om å opplyse om sine forbindelser som hovedregel må tre i habilitetsreglenes sted. Gjennom slik opplysning kan den offentlige myndighet selv ta stilling til om en bestemt megler skal engasjeres, og også vurdere de rådene som gis på bakgrunn av opplysningene om meglerens økonomiske tilknytning til bestemte selskaper i markedet.

Det ordinære med forsikringsmegling er at megleren oppnår sin provisjon uavhengig av hvilken forsikringsgiver kunden velger. I noen tilfeller kan det likevel foreligge mer særegne forhold som kan tilsi en annen konklusjon. Markedet for kommunale tjenestepensjoner skiller seg fra forsikringsmarkedet rent generelt ved at en av de store aktørene i markedet, KLP, ikke benytter seg av meglere i sin kontakt med kommunene siden det er et gjensidig selskap eiet av kommunene. Dette innebærer at muligheten for å få oppdrag er utelukket dersom kontrakten går til KLP. Forsikringsmeglere generelt vil således ha en direkte økonomisk interesse $i$ at kommunene velger en annen pensjonsleverandør enn KLP. Markedet er dessuten preget av at det bare finnes et fåtall store aktører. Dette kan gjøre muligheten for oppdrag for rådgiveren dersom kontrakten går til en annen enn KLP noe mindre avledet og fjerntliggende enn en rent generell mulighet til å bli engasjert av den som vinner konkurransen, noe som må tilsi inhabilitet for forsikringsmeglere i saker der KLP er blant tilbyderne.

Bruk av en rådgiver i utvelgelsesfasen som har klare interesser i at en av partene ikke får kontrakten, vil også lett utgjøre et brudd på det anskaffelsesrettslige likhetskravet. I tråd med vurderingene i Rt. 1998 s. 1398 Torghatten betyr dette en strengere vurdering i forhold til forvaltningsloven $\S 6$ annet ledd enn ellers. EFdomstolen har uttrykkelig presisert at tilbyderne skal behandles likt ikke bare med hensyn til de betingelser de utarbeider sine tilbud under, men også når den ordregivende myndigheten vurderer budene. ${ }^{15}$ En som har interesser i et bestemt utfall av tildelingen, må ikke kunne øve innflytelse på tildelingsprosessen.

15. Sak C-448/01, EVN AG Saml. 2003 s. I-14 527 avsnitt 47. 
I sakens tidligere faser er det imidlertid mer tvilsomt om økonomiske interesser kan tilsi inhabilitet som rådgiver. I alle fall gjelder dette i vurderingen av om en tjeneste i det hele tatt skal konkurranseutsettes eller ikke. Politisk sett kan det være stor strid om dette, og man kan fra en politisk innfallsvinkel si at det er uheldig om aktører med en klar interesse i retning av konkurranseutsetting brukes som rådgiver i forhold til dette spørsmålet. Fra en anskaffelsesrettslig innfallsvinkel må man likevel si at en slik interesse ikke utgjør noe problem. Selv om reglene ikke direkte krever at det offentlige går i markedet for å dekke sine behov, kan det vanskelig oppfattes som et anskaffelsesrettslig problem om en kommune går til markedet i større utstrekning enn nødvendig eller ut fra en sviktende vurdering av spørsmålet. Fra et forvaltningsrettslig synspunkt vil det avgjørende være om det å ha interesser i en kommersialisering kan være et slikt «særegne forhold» eller en mulighet til å kunne få oppdrag være en slik «særlig fordel» at kravene til inhabilitet er oppfylt. At en kommersiell aktør har interesse av at offentlige aktører dekker sine behov i markedet er neppe «særegent». Dersom man skulle legge det til grunn, ville habilitetsreglene i nokså vid ustrekning utelukke bruk av kommersielle aktører som rådgivere i gjennomgangen av offentlig virksomhet med sikte på å klarlegge om og hvordan det offentlige best kan dekke sine behov i markedet. Dette ville som nevnt avskjære det offentlige fra å benytte seg av tilgjengelig ekspertise innen mange felt hvor produktinformasjon og markedskjennskap bare eller i det vesentligste befinner seg hos aktører som opptrer i markedet som produsenter, forhandlere eller konsulenter.

I den fasen hvor kontraktsgrunnlaget utformes og de tekniske spesifikasjonene utarbeides, kan man diskutere om det er plass for de forvaltningsrettslige krav til inhabilitet ved siden av de særlige anskaffelsesrettslige regler om rådgiverhabilitet. Disse innebærer at dersom en aktør har generelle kommersielle interesser i forhold til anskaffelsen, vil bistand til det offentlige på en måte som gir en urimelig konkurransefordel utelukke vedkommende fra å delta i konkurransen om oppdraget, se nærmere nedenfor. Dersom bistanden er av en slik art at konkurransen ikke påvirkes, er det på den annen side liten grunn til at de forvaltningsrettslige inhabilitetsregler skal komme i veien for oppdraget så langt gjelder hensynet til konkurransen. Man kan på en måte si at anskaffelsesreglene overtar for de forvaltningsrettslige inhabilitetsregler når det gjelder å sikre nøytralitet og tillitt til at konkurransen går riktig for seg. En annen sak er at dersom det foreligger inhabilitet i forhold til andre interesser enn dem som berøres av konkurransen, må dette bedømmes i forhold til de forvaltningsrettslige regler.

Selv om habilitetsreglene ikke setter særlig stramme rammer for valg av rådgiver i de tidlige faser av en konkurranseutsetting, vil likebehandlingskravet i anskaffelsesreglene og EØS-avtalen gi visse føringer. Generelt gjelder det et krav om likebehandling og

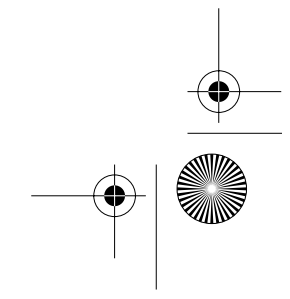


åpenhet når en offentlig myndighet går ut i markedet. Dette gjelder også ved valg av konsulenter og rådgivere for å klarlegge behov og utvikle prosjekter. Det må likevel ut fra kommersielle hensyn være adgang til å ta kontakt med en eller noen få markedsaktører for å diskutere og få bistand til å konkretisere behov og utforme konkurransegrunnlaget. ${ }^{16}$ Likebehandlingskravet vil imidlertid innebære at oppdragsgiver i slike tilfelle har en aktiv plikt til å påse at ingen foretak gis fordeler eller ulemper i konkurransen som følge av at en kommersiell aktør trekkes inn i arbeidet med å forberede en utlysning. Også likebehandlingskravet kan dermed tilsi at en aktør som har bestemte interesser utover de sedvanlige som ligger i det at han selv er en aktør ikke kan velges. Eksempel på dette kan nettopp være hvor rådgiverens interesser går i retning av å utelukke en bestemt markedsaktør fra oppdrag.

\section{Anskaffelsesrettslig inhabilitet}

Den særlige anskaffelsesrettslige habilitetsregelen i anskaffelsesforskriften § 3-6 sier at oppdragsgiver ikke skal søke eller motta råd som kan bli benyttet under utarbeidelsen av spesifikasjoner for en bestemt anskaffelse fra noen som kan ha økonomisk interesse i anskaffelsen, når dette skjer på en måte som vil kunne utelukke konkurranse. ${ }^{17}$ Formuleringen bygger på bestemmelsen om teknisk dialog i GPA (General procurement agreement under WTO) artikkel VI nr. 4 som er nærmest likelydende. Regelen må ses på bakgrunn av plikten til å likebehandle dem som konkurrerer om et offentlig oppdrag og innebærer at visse rådgivere blir utelukket fra å delta om tildeling av oppdraget. ${ }^{18}$ Selv om den er utformet som en regel om forbud mot å benytte bestemte personer som rådgivere, må den dermed også forstås som et forbud mot i visse situasjoner å la rådgivere delta i konkurransen om oppdraget. I det nye EF-rettslige anskaffelsesdirektivet er regelen kommet til uttrykk i fortalens pkt. 8 som sier at «inden de ordregivende myndigheder indleder en udbudsprocedure, kan de ved hjælp af en «teknisk dialog» søge eller modtage rådgivning, der kan benyttes til at udarbejde udbudsbetingelserne, dog forudsat at en sådan rådgivning ikke har til følge, at konkurrence forhindres».

Bestemmelsen er utslag av det generelle likhetskravet. Selv om den i forskriften er formulert som et krav rettet til utarbeidelse av

16. Slik Sue Arrowsmith, The Problem of Discussions with Tenderers under the E.C. Procurement Directives, (1998) 7 P.P.L.R 65-82.

17. Bestemmelsen er behandlet av Marianne Dragsten og Ester Lindalen, Offentlige anskaffelser, bd. I Oslo 2005 s. 629-43. For bred redegjørelse over praksis fra danske håndhevelsesorganer i forhold til reglene om teknisk dialog se Steen Treumer, Technical Dialogue Prior to Submission of Tenderers (1999) 8 P.P.L.R. s. 147-160.

18. Se Lasse Simonsen, Prekontraktuelt ansvar, Oslo 1997 s. 618-619 og Ruth Nielsen, Udbud af offentlige kontrakter, 3. utg., København 2005 s. 80. 
spesifikasjoner til en bestemt anskaffelse, må den dermed ses som en regel om råd og konsulentbistand til oppdragsgiveren mer generelt. Den anskaffelsesrettslige inhabilitetsregelen knytter seg ikke spesifikt til noen av de tre fasene som er skissert ovenfor. Uavhengig av hvilken fase rådgiveren har opptrådt i tilknytning til, må oppdragsgiver vurdere om utførelsen av oppdraget gir rådgiveren en slik fordel at han må utelukkes fra konkurransen. På den annen side vil den ha sin største praktiske betydning i forhold til arbeidet med utarbeidelse av konkurransegrunnlaget. Det er vanskeligere å tenke seg at rådgivning og bistand overfor myndigheten i en tidligere fase enn dette kan påvirke konkurransesituasjonen. I fasen etter at tilbud er inngitt, vil som påvist ovenfor de forvaltningsrettslige inhabilitetsreglene utelukke at en aktør med tilknytning til en part deltar i avgjørelsen eller tilrettelegging av grunnlaget for den.

At det forut for en anskaffelse har vært kontakt mellom den offentlige oppdragsgiver og en rådgiver, innebærer ikke at rådgiveren automatisk blir inhabil, jf EF-domstolens avgjørelse i Fabricom. EF-domstolen skiller her mellom to situasjoner som kan innebære at rådgiveren må utelukkes fra å delta i konkurransen. ${ }^{19}$ Den første er hvor «en person, der har udført visse forberedende arbejder, kan have opnået en fordel, han kan anvende ved udformningen af sit bud, som følge af de oplysninger han kunne have modtaget om den omhandlede offentlige kontrakt i forbindelse med udførelsen af de nævnte forberedende arbejder.» Den andre er hvor rådgiveren er «i en situation, der kan føre til en interessekonflikt, der, som Kommissionen for De Europæiske Fællesskaber med rette har bemærket, skal forstås således, at personen, hvis han selv byder på den omhandlede offentlige kontrakt, selv uden at have dette til hensigt, kan påvirke kontraktbetingelserne i en retning, der er gunstig for ham. En sådan situation vil kunne fordreje konkurrencen mellem de bydende.» Avgjørende er således om rådgiveren gjennom sitt arbeid for forvaltningen har oppnådd en konkurransefordel som innebærer at en likebehandling av rådgiveren og de øvrige tilbudsgivere blir umulig. Rådgiveren har for eksempel hatt mulighet til å påvirke tilrettelegging av utlysningsgrunnlaget eller fått en særlig innsikt i prosjektet og oppdragsgiverens ønsker som innebærer at han har fått en utilbørlig konkurransefordel i forhold til konkurrentene.

Hvorvidt det foreligger inhabilitet må bero på en konkret vurdering av om rådgiveren har skaffet seg en utilbørlig konkurransefordel. Viktige momenter i en slik vurdering vil være arbeidets omfang og om det kan likestilles med et ferdig prosjekt og om resultatet av rådgivningen gjøres allment tilgjengelig for alle deltakerne i konkurransen. Av særlig betydning er om rådgiveren

19. Forente saker C-21/03 og C-34/03 Fabricom SA mot Belgia, ennå ikke i Saml. premiss 29 og 30.

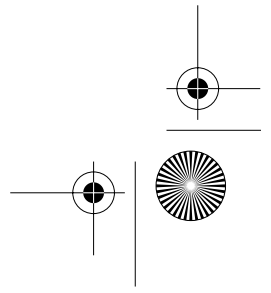


deltar i utarbeidelsen av spesifikasjoner og om samarbeidet har resultert i spesifikasjoner som er skreddersydd for rådgiverens egne produkter eller tjenester. ${ }^{20}$

I saken Media Farm som er behandlet ovenfor, hadde oppdragsgiver benyttet seg av en person som var ansatt hos en av de aktuelle tilbudsgivere som konsulent. ${ }^{21}$ Konsulenten deltok i utformingen av konkurransegrunnlagets kravspesifikasjon. Kofa fant at det forelå brudd på forskriften § 3-6. Konsulenten fikk gjennom sitt arbeid for oppdragsgiveren tilgang til kunnskap som var egnet til å gi en av konkurrentene et klart konkurransefortrinn. Konsulenten fikk inngående kunnskap om oppdragsgiverens ønsker og behov, og hvilket kvalitativt nivå konkurrentene hadde lagt seg på i den forutgående konkurransen om audiovisuelle installasjoner. Konsulentens arbeidsgiver hadde anledning til å skreddersy sitt tilbud i samsvar med denne kunnskapen.

Det bærende prinsippet for rådgivningshabilitet er oppdragsgiverens plikt til likebehandling. Anskaffelsesreglene retter seg først og fremst mot oppdragsgiver og ikke mot de potensielle leverandører og tilbydere. Dette innebærer at det først og fremst er oppdragsgivers plikt å sørge for at det ikke oppstår en situasjon hvor en potensiell tilbyder blir inhabil på grunn av bistand og oppdrag for rådgiveren. ${ }^{22}$ Dette legger for det første forpliktelser på den offentlige myndigheten i valg av rådgiver. Dette er bakgrunnen for at rådgiverinhabilitetsregelen i § 3-6 er formulert som et forbud å mot søke eller motta råd fra visse aktører under visse betingelser, og ikke som et forbud for rådgivere mot å delta i konkurranse om oppdraget. Hensynene bak bestemmelsen tilsier at oppdragsgiveren velger rådgivere som er uavhengig av leverandørmiljøet der slike finnes. ${ }^{23}$ Videre pålegger likebehandlingskravet oppdragsgiveren å dra omsorg for at den eventuelle særviten som oppdragsgiveren er kommet i besittelse av, blir gjort kjent for alle potensielle tilbydere, slik at alle deltakere stilles likt med hensyn til informasjon. Hvilken informasjon dette dreier seg om, må vurderes konkret i det enkelte tilfellet. Det er for eksempel ikke mulig helt å unngå at den som har hatt leveransen til det offentlige før utlysningen har oppnådd en viss erfaring gjennom dette som de andre ikke har. En slik erfaring kan ikke alltid bringes videre. Erfaring i seg selv kan likevel ikke utelukke en leverandør fra å delta i konkurransen om et nytt oppdrag.

20. Se til illustrasjon sak 2004-09-09 fra den danske Konkurrencestyrelsen: Klage over en boligforenings udbud af bygherrerådgivning Inhabilitet, tilgjengelig på http://www.ks.dk/udbud/ks_udtalelser/2004/klager/fuld/haar/

21. KOFA-2003-86 Media Farm AS mot Jernbaneverket Norsk Jernbanemuseum.

22. Se Hans-Joachim Priess, Distortions of Competition in Tender Proceedings s. 158.

23. Se Marianne Dragsten og Ester Lindalen, Offentlige anskaffelser, bd. I Oslo 2005 s. 630-31. 